\title{
The sacred theatrical attitude of Mozart's Requiem
}

\section{Ina HUDEA *}

Abstract: The "Sacred Theatricality study" of Mozart's Requiem does not propose an analysis of the masterpiece but tries to bring to the foreplan some stylistic premises that govern it. Mozart's fascination with the genre of opera, the intrinsic theatricality of music, which becomes a constitutive aspect of te requiem $K 626$, the blending of melodic and musical dramaturgy are the "sine qua non" of the work. Mozart's approach to sacred music, the aesthetics he has built both during his biographical and creative philosophy, is also an important point in the conceptual realization of the Requiem. Finally, we could not refute the argument of the composer's testimonies in his invaluable letters. As a conclusion, we can assert that Requiem is a culminating compositional architecture that links theatricality and sacred milestone into a supreme musical edifice, which once again confirms the incontestable Mozart genius.

Keywords: Mozart, requiem, theatricality, sacred.

Composed and made for the orchestra, choir and four soloists, in the re minor tone, The W.A. Mozart Requiem K 626 opens an unprecedented perspective to the still unspoken German romantic spirit. In this score there are moments of extraordinary melodramatic theatrical sense, but also parts of an absolute sacred classical rigor. Among the most eloquent

* $\mathrm{PhD}$, Lecturer, Music Academy "Gheorghe Dima" of Cluj-Napoca. 
dramatic inspirational moments are, of course, the famous "Lacrymosa". The composer succeeds here, using short ascending and descending chromatic motifs entrusted to the violins, coupled with a wide-ranging oral writing, to create the effect of sighing crying, a humble and devoted prayerful effect, with a "Amen" conclusive in strength, expressing sublime fervor religious. In direct contrast to "Lacrymosa", the rigorous escape from Kyrie, the choir suffers enough rhythmic and intonational precision problems, without yielding any step, however, to the drama that impregnates the entire Mozart score. Finally, a reference part of the "sacred" repertoire of many lyrical soloists, is the splendid "Tuba Mirum". In this section of the Requiem, the theatricality of the composer blends absolutely with the sacredness of the text, described during the musical labor, at the beginning individually and then by all four solist voices.

The "orchestral" thought of the instrumental vocal element, expressed by Mozart in Requiem, is marked by all the aesthetic data that led to the formation and evolution of Mozart's style as a unique alloy composed of various substances. There is no doubt that the concept of the vocal counterpoint Mozart fully embodies in Requiem lies beyond Haendel's inheritance - an author Mozart has well known, even realizing a "modernized" orchestration to the standards of the famous Orthodox Messiah. The fact that Mozart studied the Bachian polyphonic works and was influenced by them appears to us on every page of the Requiem, not only in the fugatto passages but also in many other sections which showed us rigorous contrapunctional elaboration (such as Rex tremendae, Record, Confutatis or Domine Jesu).

At Mozart, in mature works written in minor tone, the discourse shows a remarkable availability for chromaticity and "theatrical" tensions. But the concert spirit, the piquevole and the gioccoso spirit, the vivacity of the movements, the rich figurative adherence, the sleekness of the ties, are always saved by a 
splendid detachment born of the inner force of the artist defying the dead, the threat of death.

On another plane, it is interesting to note for the present study the particularity of the mozart-leaning style of the theatrical-musical genre and its interferences with the vocalsymphonic genre, as it is known that the mirage of the opera exerted a considerable influence on the way of approaching other musical genres, and Mozart was one of the composers particularly sensitive to this phenomenon of time.

Creator of an important chapter in the history of the work, W.A. Mozart is the composer who gave this genre a special weight, enriching the repertoire of the lyrical theater with immortal masterpieces. "Taking on the traditions of the musical performance, as it was during the first half of the century. XVIII, Mozart succeeds in his lyrical creation, the synthesis necessary to serve as a conclusion to the two centuries of earlier development, while setting out perspectives that open the road to romanticism. If Haydn confines himself to trying the genre of musical theater, if Beethoven directs his efforts to his unique opera, Fidelio, Mozart's heritage includes a vast expressive range of specific means, on the main coordinates of the show ${ }^{1}$. "Creator of new forms, he starts from "series work". But it pays special attention to opera buffe and to the german siengspiel (Bastien and Bastienne, 1768), imagining the very first musical fairy tale in the history of the lyrical genre (the Magic Flute).

Mozart is a great dramaturgist with his collaboration with great time literates (most notably Lorenzo da Ponte), giving them the conditions of a great diversity of portraiture, perfectly framed in the spirit of a "realistic theater". The means of musical

${ }^{1}$ Grigore Constantinescu, Daniela Caraman - Fotea, Ghid de opera (Opera guide), Bucharest, The Musical Publishing House of The Composers' Union, 1971. 
achievement of the scenarios, presumed by librettes, are extremely varied, the genius of the composer pointing here unlimited resources.

Creator of ample symphonic and vocal-symphonic forms, instrumental concerts and unique chamber works, Mozart gives the orchestral parts of his works a special attention; in orchestrations or during the performance of the work, the orchestra fulfilling the role of commentator and motivator of ideas, in a broad but differentiated treatment from work to work. Overcrowding is still featured in symphonic concert programs, being perfectly balanced, masterfully written, containing the thematic material that generates the main musical moments in the works. Also, the overall scenes: thirds, quartets, quintesses, sextets, etc., are models of theatricality and perfection, each melodic line being outlined but at the same time supporting the expressiveness of the whole.

"Mozart's music has nothing of a revolutionary like Schoenberg or an experimental like Haydn. Following Schubert's example, a few years later, he was pleased with the shapes and structures fixed by his forerunners or contemporaries. But through the perfection of writing, through the richness, the originality and the almost permanent renewal of his inspiration, through the acuity of a sensibility constantly awakening, he transcends all the schemes, all the organisms within which, contrary to Haydn, the true magician of instrumental music, in the theater he sang the most direct, purest expression of his dramatic genius" 2 .

Mozart was always fascinated by the possibilities of the socalled melodrama - that dialogue spoke with music - and his sense of theatrical effect, centered on vocal music. He clearly

${ }^{2}$ Larousse, Dictionar de mari muzicieni (Dictionary of great musicians) Bucharest, Univers Enciclopedic Publishing House, 2000, pag. 334. 
notices the difference between the music that is the equivalent of dramatic action and the music that perfectly expresses the words. The first concept has priority, and he is willing to abandon the words sung for the recited ones, when action can be more eloquent in this way. Mozart has never ceased to experience or believe that the music used for dramatic action is less important than the one symphony.

At Mannheim the composer discovers that stage music can be more than an artistic way that serves the virtuosity of the singers; it can become one and the same with her dramaturgical action and turnarounds. The main concepts that made the new musical style apt for dramatic action were: articulation of the phrase, which gives the music the character of a series of distinct events; more polarization of the sphere of tonic and dominance, which produces greater tension at the center of each work; and ultimately, but essentially, the use of the rhythmic transition, which allows the texture to change suddenly with the stage action, without endangering in any way the purely musical unity.

All the principles listed above govern the vocality in Requiem. But this time, not to serve the unity and expressiveness of the scenic action, but to emphasize the primordial affections of the words of the sacred text, and so gravel them in the most sensible way in the listener's consciousness.

There are important points of reference in Mozart's sacred creation. In Salzburg, in the service of Archbishop Hieronymus von Colloredo, he had the express task of composing cult music. That's how many mistakes appeared, and other sacred music creations. According to the Köchel Catalog, the most popular are:

KV 201765 Motet (Psalm 46:I)

KV 331766 Kyrie for chorus and string orchestra in Major Fa 
KV 34 1766/7 Offertorium for soprano, orchestra and chorus, "In Festo St. Benidicti"

KV 441770 Antifon (Introitus) Cibavit for chorus and organ (assigned)

KV 471768 Offertorium "Veni, Sancte Spiritus" for orchestra and chorus in Do major

KV 491768 Misa brevis in Sol major

KV 61a 1769 Misa brevis (KV 65) in Re major

KV 651769 Misa brevis (KV 61a) in re minor

KV 661769 Misa „Dominicus” in Do major

KV 721778 Offertorium for orchestra, chorus and organ "Inter natos mulierum" in Sol major

KV 851770 Miserere for chorus and bass

KV 861770 Antifon for chorus Quaerite primum regnum Dei

KV 891772 Kyrie - canon for 5 major sopranos

KV 901771 Kyrie for chorus and organ (assigned) in re minor

KV 911774 Kyrie in Re major (composed maybe by Süssmayr)

KV 931771 Psalm De Profundis clamavi

KV 1151773 Misa brevis in Do major

KV 1161771 Misa brevis in Fa major

KV 1171769 Offertorium in Do major

KV 1391768 Misa solemnis in Do minor

KV 1401771 Misa brevis (atribuit) in Sol major

KV 1411769 Te Deum in Do major 
KV 1651773 Exsultate, jubilate, motet for sopran and orchestra

KV 1671773 Misa in Do major

KV 1921774 Misa brevis in Fa major

KV 1931774 Dixit şi Magnificat in Do major

KV 1941774 Misa brevis in Re major

KV 1951774 Litaniae Lauretanae in Re major

KV 2201775 Misa brevis in Do major

KV 2211771 Kyrie in Do major

KV 2221775 Offertorium de tempore „Misericordias Domini" in Re minor

KV 2231773 Osana (fragment) in Do major

KV 2571776 Misa Credo in Do major

KV 2581776 Misa brevis „Spaur” in Do major

KV 2591776 Misa brevis orga solo in Do major

KV 2601776 Offertorium „Venite, Populi”

KV 2621776 Misa Longa in Do major

KV 2751777 Misa brevis in Sib major

KV 2761779 Regina Coeli in Do major

KV 2771777 Offertorium "Alma Dei creatoris"

KV 3171779 Misa Coronation in Do major

KV 3221778 Kyrie (fragment) in Mi major

KV 3231779 Kyrie (fragment) in Do major

KV 3371780 Misa solemnis in Do major 
KV 4271780 Misa in Do minor (Grosse Messe)

KV 6261791 Requiem

The fact that Archbishop Hieronymus von Colloredo did not particularly appreciate the music and minimized her role in the Salzburg ceremonies and ceremonies, as well as the inevitable rupture of the stormy professional relationship with Mozart, diminished his obligation to intensely cultivate these genres, but the works that remained (the above mentioned) the composer combined the expressiveness with the technical skill and cultivated the most modern solutions of his time, including the bending towards the sensibility and the spectacular spectacle from the taste for the opera.

With his move to Vienna and the launch of an independent career, the occasions of composing sacred music have greatly diminished, the preference of the young genius towards opera, instrumental concert, symphony and chamber music.

In the correspondence of the great composer there are quite a few fragments referring strictly to religious music. From the whole context of his Letters, however, one can deduce some characteristic features of the Mozart's personality. On the one hand, the joy and exuberance (which we find in the works of buffets, sonatas, concerts, etc.) and on the other hand the profoundness of thoughts and feelings about respect for parents, moral and spiritual values.

A first important reference to a religious music are in a letter to his father on 4 November 1777. Mozart wrote "(...) Now I want to talk about music here. We were on Saturday, on All Saints' Day, at Chapel, at a solemn liturgy. I found a big orchestra and great every game by 10,11 violins, four violas two oboes, two flutes, two clarinets, two horns, four cellos, four bass, trumpets and timpani. It could make beautiful music, but I would not have the courage to present here a missile written by me. Why? 
Because of shortness? No, here it must be all short. Because of the church style? Much less. Here, in the current situation, it is mainly composed of instruments. You can not imagine anything weaker than the group of voices: 6 sopranos, 6 altists, 6 tenors and six basses, compared to 20 violins and 12 basses. (...)"3. From these lines we recognize the importance that Mozart gave to the conceptual and structural aspect of a religious work. We can easily figure out the weight of the instrument's voice (and not vice versa) for the young but already experienced composer.

A deep respect for the use of tradition in church music is also apparent from the Vienna letter of 12 April 1783, also intended for his father: "If you still warm up, please look through the bridge and send us some of your music (...) tastes always change, the change of taste has spread even to church music. But that should not have happened. From where it follows that true church music is found in the attic and is almost eaten by moths"4.

Missa in the minor KV427 (1782-1783), also known as the Great Miss, was composed by Mozart (but unfinished) as a gesture of offering for the recovery of his future wife, Costanza.

In Salzburg, Mozart arrived with more than half of the Missa score. Kyrie and Gloria were complete, Sanctus and Benedictus, partially finished (not fully covered), there was also a draft of Credo and Agus Dei was not yet started.

The celebration of the ministry took place in Benedictine St. Pietro, with pieces of various sacred compositions, and not in the Salzburg Cathedral (as the composer wanted) that was subordinated to Colloredo who had not forgotten the humiliating interruption of professional relations between him and Mozart.

3 Wolfgang Amadeus Mozart, Scrisori( Letters), Bucharest, The Musical Publishing House of The Composers' Union from R.P.R, 1968 (translated by Cristian Ghenea after Wolfgang Amadeus Mozart Briefe, herausgegeben von Willi Reich, 1948 Manesse Verlag - Zürich)

${ }^{4}$ Ibidem. 
After this event, the composer's genius never worked on this work, although he used Kyrie and Gloria here in a later work.

The Great Missa is actually the return of Mozart to sacred music, after the Saxon years, a return that will be fully felt in Requiem. For the first time, he will compose a barrage without obstacles and stylistic rules imposed by Archbishop Colloredo.

So we do not have to be surprised if in the Great Missa there is a breakthrough of fantasy and inspiration not seen in Mozart's sacred music ever since.

Kyrie debutes with a short orchestral introduction, whose drama is highlighted by blowers before the choir's entrance with that wonderful "archaic" impost. Christe eleison "sweeps" the musical atmosphere that then comes through the resumption of Kyrie, to the drama of the beginning part.

Gloria - a very broad section - consists of 7 episodes: Laudamus te (cantabile), Domiine Deus (with contrapunctic accompaniment to strings), Quoniam (tertiary), Jesu Christe (an adagio) How Sanctu spirit complex structure), suggestive Qui tollis (in minor soil with double chorus at 8 voices and ostinat bass). Kyrie and Gloria, remain somewhat of a preference for the composer because, as mentioned above, they will be used by Mozart in the oratorio Davidde Penitente K469.

Credo, even if it was just a sketch, contained enough information to be further edited by publishers, faithfully enough to the intentions of the composer.

Sanctus, which culminates in the double run in Osanna, is written for 5 voices (like Credo) and has an expressivity of unusual intensity.

Benedictus is a section that brings together both formal complexity and melodic refinement.

In the history of music, Missa in do minor by W.A. Mozart is a crossroads of sacred music and can easily be considered the bridge between Missa in and minor by J.S Bach with Missa 
solemnis in Re major by L.van Beethoven. It is also the germinative conceptual essence of the future Messa da Requiem.

We consider it necessary in this moment of the discourse, to review some historical and structural references of the Requiem. Messa da Recviem - Messa for the dead (Messa pro defunctis) of the Roman Catholic Church, comes from the first word of prayer at the beginning of the ministry, "Requiem aeternam donna eis, dominates". The texts of this prayer (as well as messa itself) are often referred to as "Requiem" only ${ }^{5}$.

Messa da Requiem is played in the memory of the faithful souls who have crossed the threshold of earthly life, and was part of the same class as the dedication tables; that is, it was not closely linked to just one day. It could also be played on funeral days, as well as three, seven and thirty days after the end of life. The parts of the table are: prayer at the beginning of the liturgy, Requiem aeternam, Kyrie; graduate (Requiem aeternam) and tract (hymn sung instead of Alleluia); the sequence (Dies irae, dies illa), collect (Domine Iesu Criste) Sanctus and Benedictus, Agnus Dei and communion, respectively communion (Lux aeterna luceat eis, Domine); the hymn of response (antiphon) Free me, Domine was singing after sacrifice on solemn occasions. Except for the local variants, the liturgical and musical dialects, the Requiem crystallized its structure until the 14th century; the sequence being the last part to be added.

Before the Reforms of the Council of Trento (1543-1563) another gradual ( $\mathrm{Si}$ ambulem in medio umbrae mortis) and the tract (Sicut cervus desiderat ad fontes, aquarum) could be used to reflect the liturgical tradition. After the Council, only Requiem aehnam and Absolve were approved. The council also approved the keeping of the Dies irae sequence. The liturgy for the dead, a separate liturgical ritual that did not overlap with Messa da Requiem, did not

${ }^{5}$ Give them eternal rest, O Lord! 
represent too much interest for the composers, although polyphonic arrangements were often made for this type of job. Here is a comparison of the texts of the mission and the requiem:

MESSA

I. Kyrie

I. Introitus

\section{REQUIEM}

Requiem aeternam

Kyrie eleison

Christe eleison

Kyrie eleison

II. Gloria

Gloria in excelsis

Et in terra pax

Laudamus te

Gratias agimus tibi

Domine Deus

Qui tollis peccata mundi
Kyrie eleison

Christe eleison
Kyrie eleison

\author{
II. Sequenza
}

Dies irae

Tuba mirum

Mors stupebit

Liber scriptus

Quid sum miser

Rex tremendae 
Qui sedes ad dexteram Patris

Quoniam tu solus sanctus

Cum Sancto Spiritu

Lacrimosa

III. Credo (Symbolum Nicenum)

Credo in unum Deum

Patrem omnipotentem

Et in unum Dominum

Et incarnatus est

Crucifixus

Et resurrexit

Et in Spiritum Sanctum

Confiteor

Et expecto

IV. Sanctus, Benedictus
Recordare

Ingemisco

Confutatis

III. Offertorium

Domine Jesu Criste

Hostias 
Sanctus

Hosanna

Benedictus

Hosanna

Sanctus

Hosanna

Benedictus

Hosanna

\section{Agnus Dei}

Dona nobis pacem

\section{Communio}

Lux aeterna

VII. Libera me

Libera me

Dies irae

Requiem aeternam

Libera me

The Mosaic Requiem consists of 12 parts, of which six are on liturgical texts that are part of the funeral service, the rest are based on the strofs of the famous Latin poetic text dating back to the 13th 
century, the Dies Irae, dies illa (Day of Wrath, that day) that reflects the idea of eternal punishment of sinners. This poetic text is usually played on an old Gregorian melody, whose expressive and connotative force has attracted its symbolic use by many composers - Berlioz, Liszt, Saint-Saëns, Rahmaninov, Haciaturian and others. Mozart did not use anywhere in his old Gregorian song. Each part of Requiem has a well-outlined melodic, rhythmic and harmonic character. "The songs of a pervasive lyricism and others with shrill accents of pain and passion, melted rhythms and orchestral outbursts and vigorous corals, render the images of the poetic text"1. By the sober but imposing vocal and orchestrative means used by the author, the work seems to have been intended for concert halls rather than the church. In fact, the first audition, in 1792, took place in Vienna in a concert hall.

After Mozart's death, his widow, Constanze, entrusts the completion of the Requiem (based on numerous sketches left by Mozart) to his three husband's students, who would have come close to the original intentions of the great composer: Joseph Eybler, Franz Freistadler and finally, Franz Xaver Süssmayr, who will make his most significant contribution to the completion of Mozart's mosque (the last four parts of Dies Irae, Sanctus, Benedictus, Agnus Dei).

A large number of contemporary testimonies attest that Mozart had thought about his own death during the writing of the Requiem. Even after overcoming the fanciful exaggerations (combined with the effect of the legend of poisoning), there remains sufficient reason to believe that there is a part of truth in what Niemetschek wrote in 1798 . Very soon after he debuted with the composition of the work "Mozart began talks about death and says he writes the Requiem for himself ${ }^{1}$. Also credible is the

1 Wolfgang Amadeus Mozart, Scrisori ( Letters), Bucharest, The Musical Publishing House of The Composers' Union from R.P.R, 1968 (translated by 
testimony of her sister-in-law, Sophie Haibl, who remembered in 1825: "The last thing he did was to try to murmur the sound of the tympanians in his Requiem; as I hear it now ...2 "When Mozart received the command and began to prepare his work, you could hardly find any reason or at least a suspicion to explain his imminent death, especially from the perspective of an exceptional job difficult, which the composer submitted in autumn 1791.

Not long after, he was shot down by severe illness, and he undoubtedly realized the gravity of the situation, but was too absorbed by the work at his composition, which he had not been able to complete. Thus, the idea of a "death reminder" has become overwhelming as the moment of cessation of work has come close. A few years before, on April 4, 1787, Mozart wrote to his father Leopold, who was on the deathbed:

"I really need to tell you how much I look for to get some comforting news from you. And while I wait, I still have a habit of being prepared for what may be worse in life. Like death, for example, when we come to look at it closer, as the true goal of our existence. Death, with which I have established close relationships in recent years, as well as a good friend of all mankind, so that her image will not frighten me, but I will really see it soothing and comforting! And I thank God for the divine grace he gave me (you know what I mean) to learn that death is the key that opens the door to our true happiness. And it is not a night to fall asleep without thinking - as young as I am - that I may not live to see another day ${ }^{3}$.

Cristian Ghenea after Wolfgang Amadeus Mozart Briefe, herausgegeben von Willi Reich, 1948 Manesse Verlag - Zürich)

${ }^{2}$ Ibidem.

3 Wolfgang Amadeus Mozart, Scrisori (Letters), Bucharest, The Musical Publishing House of The Composers' Union from R.P.R, 1968 (translated by Cristian Ghenea after Wolfgang Amadeus Mozart Briefe, herausgegeben von Willi Reich, 1948 Manesse Verlag - Zürich). 
"We can not know exactly how and where this profound manner of reflection on life has left its mark on music and the process of creation. But we know that the "pathetic style" of the Requiem is not an abstract aesthetic license but a creation in which maturity Mozart's musical band unites its powers with an unprecedented need for expression.

\section{References}

1. *** Ghid de opera (Opera guide), Bucharest, The Musical Publishing House of The Composer's Union, 1971.

2. *** Larousse, Dictionar de mari muzicieni (Dictionary of great musicians), Bucharest, Univers Enciclopedic Publishing House, 2000.

3. Balea, Ilie, Dialogul artelor (The dialogue of Arts), Bucharest, Publishing House for Literature, 1969.

4. Bălan, George, $O$ istorie a muzicii europener A History of European Music), Bucharest, Albatros Publishing House, 1975.

5. Brophy, Brigid, Mozart the Dramatist, Harcourt, Brace \& World, New York, 1964.

6. Brumaru, Ada, Grădina sunetelor - Eseuri despre musică (Garden of Sounds - Essays on Music), Bucharest, The Musical Publishing House of UCMR, 1991.

7. Lang, Paul Henry, The Creative World of Mozart, Norton \& Company, Inc., New York, 1963.

8. Mozart, Wolfgang Amadeus. Scrisori (Letters), Bucharest, The Musical Publishing House of The Composer's from R.P.R, 1968 Wolff, Christoph, Mozart's Requiem, University of California Press, Berkeley, 1994. 